\title{
Towards in situ U-Pb dating of dolomite
}

\author{
Bar Elisha $^{1,2}$, Perach Nuriel ${ }^{1}$, Andrew Kylander-Clark ${ }^{3}$, and Ram Weinberger ${ }^{1,2}$ \\ ${ }^{1}$ Geological Survey of Israel, Jerusalem, Israel \\ ${ }^{2}$ Department of Earth and Environmental Sciences, Ben-Gurion University, Be'er Sheva, Israel \\ ${ }^{3}$ Department of Earth Sciences, University of California, Santa Barbara, CA, USA
}

Correspondence: Bar Elisha (brelisha@bgu.ac.il)

Received: 11 June 2020 - Discussion started: 26 June 2020

Revised: 27 March 2021 - Accepted: 12 April 2021 - Published: 26 May 2021

Abstract. Recent $\mathrm{U}-\mathrm{Pb}$ dating by laser ablation inductively coupled plasma mass spectrometry (LA-ICP-MS) has demonstrated that reasonable precision $(3 \%-10 \%, 2 \sigma)$ can be achieved for high-resolution dating of texturally distinct calcite phases. Absolute dating of dolomite, for which biostratigraphy and traditional dating techniques are very limited, remains challenging, although it may resolve many fundamental questions related to the timing of mineral-rock formation by syngenetic, diagenesis, hydrothermal, and epigenetic processes. In this study we explore the possibility of dating dolomitic rocks via recent LA-ICP-MS dating techniques developed for calcite. The in situ U-Pb dating was tested on a range of dolomitic rocks of various origins from the Cambrian to Pliocene age - all of which are from wellconstrained stratigraphic sections in Israel. We present imaging and chemical characterization techniques that provide useful information on interpreting the resulting $\mathrm{U}-\mathrm{Pb}$ ages and discuss the complexity of in situ dolomite dating in terms of textural features that may affect the results. Textural examinations indicate zonation and mixing of different phases at the sub-millimeter scale $(<1 \mu \mathrm{m})$, and thus TeraWasserburg ages represent mixed dates of early diagenesis and some later epigenetic dolomitization event(s). We conclude that age mixing at the sub-millimeter scale is a major challenge in dolomite dating that needs to be further studied and note the importance of matrix-matched standards for reducing uncertainties of the dated material.

\section{Introduction}

Recent developments in laser ablation inductively coupled plasma mass spectrometry (LA-ICP-MS) have opened a new avenue for measuring absolute ages of carbonates, thus improving the understanding of many fundamental geological processes, such as fossilization ( $\mathrm{Li}$ et al., 2014), tectonic faulting (Ring and Gerdes, 2016; Roberts and Walker, 2016; Nuriel et al., 2017; Parrish et al., 2018), duration of sedimentation, and diagenesis (Hodson et al., 2016; Godeau et al., 2018). Despite the low concentrations of $U$ and radiogenic $\mathrm{Pb}$ in carbonates $(<10$ and $<2 \mathrm{ppm}$, respectively) as well as the considerable amounts of initial $\mathrm{Pb}$ (up to $100 \mathrm{ppm}$ ), a reliable age determination of calcite is obtained via isochron regression on a Tera-Wasserburg inverse concordia diagram (Tera and Wasserburg, 1972). With this method, the initial $\mathrm{Pb}$ composition and the age are determined by the upper and lower intercept of the regression isochron with the concordia curve. While LA-ICP-MS analyses of calcite evolved to be a conventional method of dating (Roberts et al., 2020), a thorough methodology for dating other carbonates, such as dolomite, is still needed (Guillong et al., 2020).

Dolomite is vastly abundant in exposed stratigraphic sequences, and its manifestation in the geological record increases towards older sedimentary strata (Warren, 2000). Nonetheless, it is very rare in modern environments and has seldom been successfully grown in laboratory experiments at near-surface conditions (Machel, 2004, and references therein). Although the conditions and kinetics promoting dolomite growth are not well understood, its formation is considered a by-product of chemical reactions between $\mathrm{Mg}$-rich fluids and calcite-bearing rocks. Previous studies suggested that dolomite is formed either by diagenetic re- 
placement of limestone during deposition (syngenetic; Sass, 1969), soon after deposition (early diagenetic; Ahm et al., 2018; Frisia et al., 2018), or at a later stage (epigenetic; Gregg and Sibley, 1984). Distinguishing between different dolomitization processes is challenging yet critical for resolving some of the issues and ambiguities related to the formation of dolomitic rocks. Accurate $\mathrm{U}-\mathrm{Pb}$ absolute dating of dolomite by LA-ICP-MS could contribute to a better understanding of the dolomitization process by placing these event(s) in the proper geological context. However, dating dolomitic rocks is more challenging than dating calcite, particularly because their complicated growth history is often characterized by the formation of multi-phase microcrystalline grains (e.g., partial replacement, zoning). Growth zones cannot be separated physically, and their size is often smaller than the diameter of the laser spot (usually $>50 \mu \mathrm{m}$ ). In addition, well-characterized dolomite reference materials (RMs) are currently unavailable for the LA community, and differences between calcite and dolomite in terms of the matrix effect and plasma efficiency are not well understood (Guillong et al., 2020).

Previous U-Pb dating of dolomite on whole-rock samples of U-rich dolostones, conducted at the highest level of cleanroom standards, yielded scattered ages (Winter and Johnson, 1995; Hoff et al., 1995; Ovchinnikova et al., 2007; Polyak et al., 2016). These studies suggested that in situ dating of dolomites should be feasible, and indeed several studies recently reported the successful in situ age determination of dolomite using the LA-ICP-MS methodology (Burisch et al., 2018; Salih et al., 2019; Hu et al., 2020; Mueller et al., 2020). In order to examine the suitability of conventional LA-ICP-MS calcite procedures for dolomite geochronology by using common RMs, we studied dolomitic rock samples from Israel with well-defined stratigraphic ages. We show how differences in texture, crater morphology, detrital impurities, and down-hole fractionation trends between RMs and dolomite can affect the resulting ages and discuss textural characteristics and chemical properties of successful and unsuccessful dolomite dating. Finally, we consider the age results in the geological context of the studied rocks.

\subsection{Studied dolomites}

Dolomitic rocks in Israel and environs include syngenetic to early diagenetic dolomites, epigenetic dolomites, hydrothermal dolomites, and mixed or hybrid ones. This study was applied to dolomite rocks whose ages are well constrained by field relations and dates of adjacent geological units (Fig. 1). Thin-section scans and representative photomicrographs of each studied sample are provided in Fig. 1 and are described in the following sections. Cathodoluminescence images of representative carbonate material, used to infer slight changes in fluid composition (e.g., $\mathrm{Mn}^{2+}, \mathrm{Fe}^{2+}$ content) and/or precipitation conditions, are presented in Fig. 2 .

\subsubsection{Syngenetic Cambrian dolomites and hydrothermal dolomites (Timna Valley)}

Cambrian sediments are exposed in southern Israel and unconformably overlie Precambrian crystalline basement rocks of the Arabian-Nubian Shield (Fig. 1; Beyth et al., 1999). In the Timna Valley, southern Israel, Cambrian dolomitic rocks of the Timna Formation are well known for their copper deposits and ancient to present-day mining, and they are considered to have formed as early diagenetic in a marine environment at $25-50^{\circ} \mathrm{C}$ (Segev, 2016). Based on fluid inclusions and petrographic studies, Eliyahu et al. (2017) suggested that the Timna Formation dolomites were formed in high temperatures, and the dolomites are epigenetic in nature. Dolomitic rocks of the Timna Formation (sample Tm-MU-2; Table 1) represent the earliest oceanic transgression in the area, constrained by trilobite burrowing to upper Georgian $(\sim 520 \mathrm{Ma}$; Parnes, 1971) and by a dike intrusion dated to $\sim 532 \mathrm{Ma}$ (Beyth and Heimann, 1999). Sample Tm-MU-2 (Fig. 1) is composed of reddish sparry dolomite grains $<10 \mu \mathrm{m}$ in size, with minor iron oxides scattered within the sample.

Dolomite veins of later epigenetic diagenesis (Sample TmDV-1; Fig. 1) are found in the crystalline basement rock and sandstones in Timna Valley, in association with copper, quartz, calcite, and $\mathrm{Mn}$ and Cu carbonates. Sample Tm-DV1 is composed of euhedral zoned dolomite crystals of up to $200 \mu \mathrm{m}$, with opaque cores and transparent rims. It was previously suggested that these euhedral dolomite crystals of epigenetic open-space-filling cements, associated with $\mathrm{Cu}$ mineralization, are related to low-temperature $\left(\sim 260^{\circ} \mathrm{C}\right.$; Beyth et al., 1997) hydrothermal activity and mineralization assumed to have occurred during Neogene times (Kohn et al., 2019). On the other hand, Eliyahu et al. (2017) suggested that all $\mathrm{Cu}$ mineralization in the Timna Valley is associated with epigenetic hydrothermal dolomite mineralization, driven by basinal fluids. The zoned hydrothermal dolomite grains of sample Tm-DV-1 are slightly zoned under CL (Fig. 2) with very similar luminescence, suggesting minimal changes in fluid composition and/or precipitation conditions.

\subsubsection{Syngenetic and early diagenetic dolomites (Mount Carmel and Umm el Fahm Ridge)}

Dolomitic rocks dominate the exposed Cretaceous sequence of Mount Carmel, Umm el Fahm Ridge, and the Judean Mountains, which were part of an extensive shallow carbonate platform. The studied Cenomanian dolomitic rocks of the Deir Hanna Formation (Fig. 1) are exposed on the SE flank of the Umm el Fahm anticline near the village of Mei-Ami (Sass et al., 2013). These rocks are underlain and overlain by volcanic flows that are dated to $99 \pm 0.5$ and $95 \pm 0.5 \mathrm{Ma}$, respectively (Ar-Ar; Segev et al., 2002). They were described as syngenetic dolomites based on preferred orientations of dolomite grains, with a c-axis maximum perpendicular to the bedding planes (Sass, 1969). Sam- 

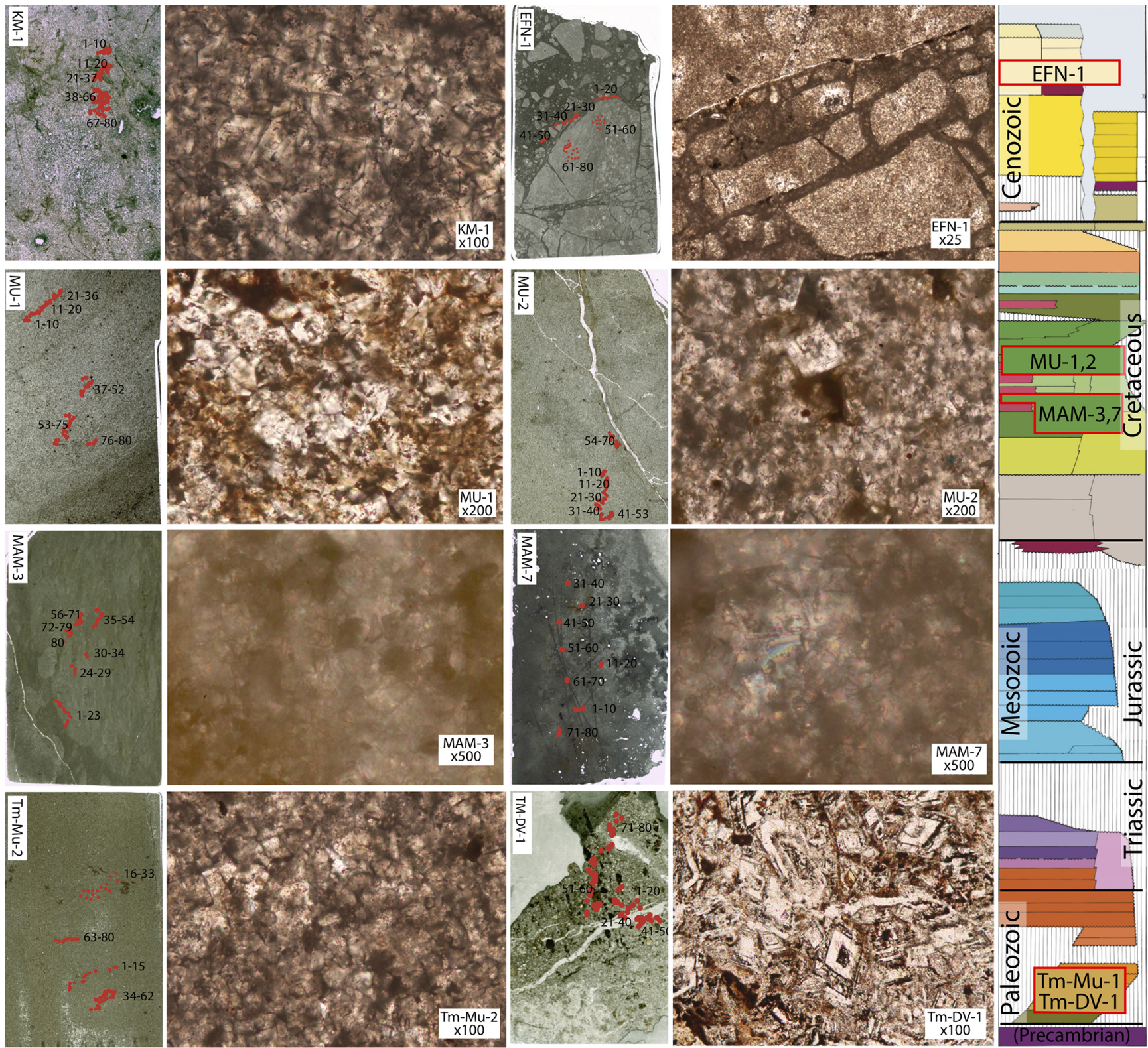

Figure 1. Thin-section scans and representative photomicrographs of each dolomitic sample from this study. Red dots on thin-section scans show the locations of LA-ICP-MS analyses. The width of thin sections is $27 \mathrm{~mm}$. Sample locations along the stratigraphic column of Israel are also provided in the right panel.

ples MAM-3 and MAM-7 (Fig. 1) are composed of finegrained $(<10 \mu \mathrm{m})$ micritic dolomite, which reflects continuity of reefs along fine-grained, well-bedded shelf basin rocks (Sass and Bein, 1978).

Dolomitic rocks of the Zikhron Formation from Mount Carmel are considered "early diagenetic" (Sass and Bein, 1978; Segev and Sass, 2009; Fig. 1) and crop out between two volcanic flows of $97 \pm 0.5$ and $95 \pm 0.5 \mathrm{Ma}$ (Segev, 2009). Samples MU-1 and MU-2 (Fig. 1) are composed of $\sim 40 \mu \mathrm{m}$ dolomite grains and represent sparry dolomite mosaic of similar ages as MAM-3 and MAM-7. Dolomitic rocks from the Albian Yagur Formation crop out near the Kerem Maharal village and are overlain by the oldest (99 Ma) volcanic flow known in Mount Carmel. Sample KM-1 (Fig. 1) is a sparry dolomite with $\sim 60 \mu \mathrm{m}$ dolomite grains and is considered an early diagenetic dolomite. The non-homogenized luminescence of the sparry sample KM-1 (Fig. 2) may indicate a possible mixture of phases that precipitated under different conditions. 
Table 1. Sample description, stratigraphic age, and their corresponding LA results.

\begin{tabular}{lrrllrrr}
\hline Sample & Latitude & Longitude & $\begin{array}{l}\text { Petrographic } \\
\text { description }\end{array}$ & $\begin{array}{l}\text { Stratigraphic } \\
\text { age }\end{array}$ & $\begin{array}{r}\text { U-Pb } \\
\text { age }\end{array}$ & MSWD & Initial Pb value \\
\hline Tm-MU-2 & 29.471561 & 34.591990 & Micritic & Cambrian & $277 \pm 59$ & 0.53 & $0.8664 \pm 0.006$ \\
Tm-DV-1 & 29.778567 & 34.977663 & Hydrothermal & Miocene & $37 \pm 75$ & 0.27 & $0.8385 \pm 0.004$ \\
MAM-3 & 32.504359 & 35.141783 & Micritic & Cretaceous & $137 \pm 14$ & 0.63 & $0.7899 \pm 0.005$ \\
MAM-7 & 32.496742 & 35.150912 & Micritic & Cretaceous & $173 \pm 11$ & 1.6 & $0.8427 \pm 0.003$ \\
MU-1 & 32.671247 & 35.092221 & Sparry & Cretaceous & $58 \pm 5$ & 5.4 & $0.8046 \pm 0.004$ \\
MU-2 & 32.671516 & 35.092353 & Sparry & Cretaceous & $93 \pm 7$ & 2.4 & $0.8064 \pm 0.004$ \\
KM-1 & 32.641733 & 34.981380 & Sparry & Cretaceous & $55 \pm 6$ & 1.3 & $0.7862 \pm 0.033$ \\
EFN-1 fragments & 31.716563 & 35.448523 & Sparry & Unknown & $74 \pm 3$ & 0.99 & $0.8140 \pm 0.021$ \\
EFN-1 cement & 31.716563 & 35.448523 & Sparry & Unknown & $6.5 \pm 1$ & 1.5 & $0.7853 \pm 0.005$ \\
\hline
\end{tabular}
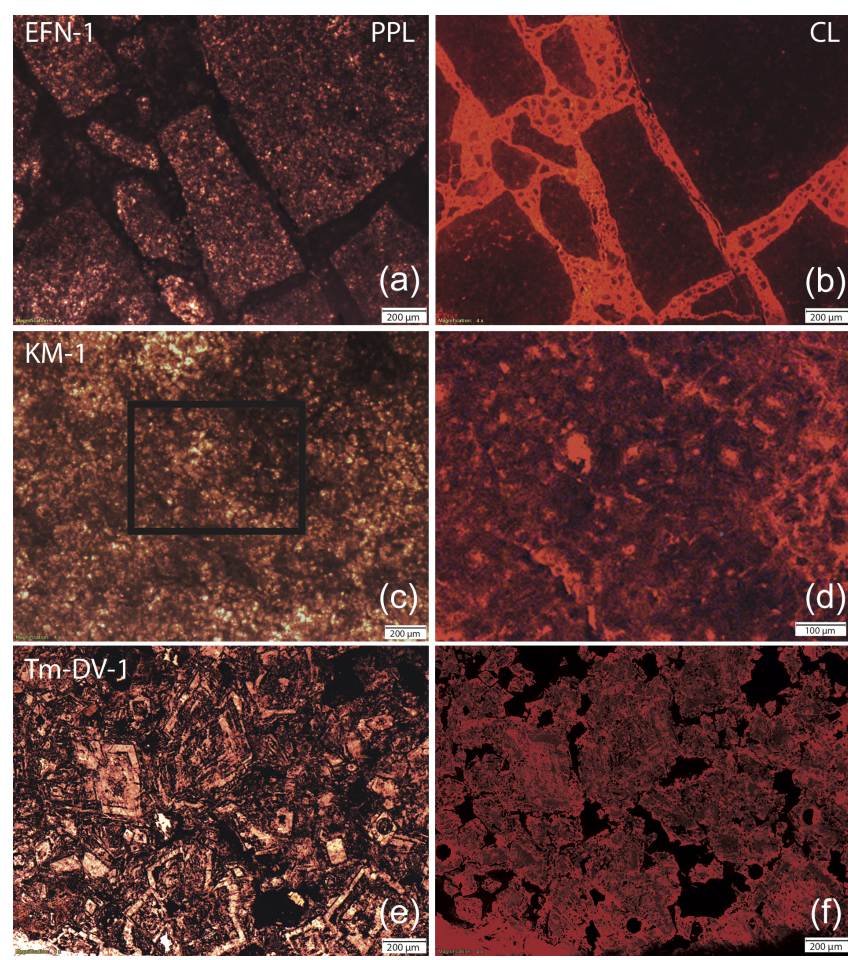

Figure 2. Plane-polarized light (PPL) images (a, c, e) and cathodoluminescence $(\mathrm{CL})$ images $(\mathbf{b}, \mathbf{d}, \mathbf{f})$ of representative studied samples. Note the differences in CL colors of breccia fragments and cement in sample EFN-1, the non-homogenized CL response in sample KM-1, and the zoned dolomite crystals in sample Tm-DV-1.

\subsubsection{Fault-related epigenetic dolomitization of early diagenetic dolomites (Judean Desert)}

Strata of dolomitic rocks are abundant at the western margin of the Dead Sea basin and include the Cenomanian Hevion, Zafit, and Tamar formations (Sneh and Avni, 2016). These dolomitic rocks are considered early diagenetic dolomites that were later faulted and cemented by epigenetic dolomite during the activity along the Dead Sea fault. Dolomitecemented breccias were sampled along one of the major faults of the Dead Sea western margin fault zone (En Feshkha Fault; sample EFN-1; Fig. 1) and preserve microstructures of mosaic (sparry) dolomite fragments bounded by sparry dolomite cement. The bright luminescence of the cement material in sample EFN-1 suggest a single phase of precipitation that is distinctively different from precipitation conditions of the fragment material (Fig. 2).

\section{Methods}

For LA-ICP-MS analyses of dolomites we prepared $40 \mu \mathrm{m}$ thick thin sections polished to $1 \mu \mathrm{m}$. U-Pb LA-ICP-MS analyses were performed at the Department of Earth Science, University of California, Santa Barbara, following the analytical procedure described in Nuriel et al. (2017) for calcitebearing rocks. Samples were ablated using a Photon Machines $193 \mathrm{~nm}$ ArF Excimer laser equipped with a HelEx ablation cell and coupled to a $\mathrm{Nu}$ Instruments Plasma 3 multicollector ICP-MS. Both RMs and unknowns were ablated with a similar spot size of $85 \mu \mathrm{m}$ and fluence of $\sim 1 \mathrm{~J} \mathrm{~cm}^{-2}$. In order to remove any contaminants, especially initial $\mathrm{Pb}$ from the sample surface, all samples were cleaned with methanol and pre-ablated (four pulses) prior to a $20 \mathrm{~s}$ baseline. Material was then ablated for $15 \mathrm{~s}$ at $10 \mathrm{~Hz}$, resulting in a pit depth of $\sim 15 \mu \mathrm{m}$. On the MC-ICP-MS, masses of ${ }^{202} \mathrm{Hg},{ }^{204} \mathrm{~Pb},{ }^{206} \mathrm{~Pb},{ }^{207} \mathrm{~Pb}$, and ${ }^{208} \mathrm{~Pb}$ were measured on Daly detectors, and masses of ${ }^{232} \mathrm{Th}$ and ${ }^{238} \mathrm{U}$ were measured on Faraday detectors at low resolution $(300,10 \%$ valley definition) using an integration time of $100 \mathrm{~ms}$. We used a two-step standardization technique with NIST614 glass and the WC-1 calcite reference material (Roberts et al., 2017) following the procedure outlined in Nuriel et al. (2017). Data were reduced using Iolite v. 2.5 (Paton et al., 2010), and the ${ }^{238} \mathrm{U} /{ }^{206} \mathrm{~Pb}$ and ${ }^{207} \mathrm{~Pb} /{ }^{206} \mathrm{~Pb}$ ratios for each analysis were plotted on Tera-Wasserburg diagrams using Isoplot and IsoplotR (Ludwig, 2012; Vermeesch, 2018); U and $\mathrm{Pb}$ concentrations were calculated semi-quantitatively using NIST614 as the primary reference material (RM). Uncertainties $(2 \sigma)$ were propagated on individual unknown ratios such that ${ }^{207} \mathrm{~Pb} /{ }^{206} \mathrm{~Pb}(2 \%)$ and ${ }^{206} \mathrm{~Pb} /{ }^{238} \mathrm{U}(4 \%)$ ra- 
tios of a zircon standard, run throughout the session (mud tank; Black and Gulson, 1978), yielded a single population; this resulted in reasonable mean square weighted deviations (MSWDs) for the calculated ages of calcite RMs. Secondary calcite RMs - ASH-15 (2.9646 $\pm 0.01 \mathrm{Ma}$; Nuriel et al., 2021) and Duff Brown (64 $\pm 0.7 \mathrm{Ma}$; Hill et al., 2016) - yielded dates within uncertainty of their accepted values (ASH-15: $2.973 \pm 0.09$, MSWD = 1.3, $n=107$; Duff Brown: $63.2 \pm 2.3 \mathrm{Ma}, \mathrm{MSWD}=1.9, n=106)$. Uncertainty correlations are calculated following Schimtz and Schoene (2007). The $\mathrm{Pb}$ concentration for each spot analysis was calculated by the total counts of $\mathrm{Pb}$ isotopes compared to the NIST glass value $(2.32 \mathrm{ppm})$. The ${ }^{204} \mathrm{~Pb}$ concentration was calculated using the ${ }^{206} \mathrm{~Pb}$ concentration and assuming a Stacey-Kramers ${ }^{206} \mathrm{~Pb} /{ }^{204} \mathrm{~Pb}$ ratio to avoid difficulties related to the $\mathrm{Hg}$ interference on ${ }^{204} \mathrm{~Pb}$.

Following LA analyses, we used several techniques to characterize the studied dolomite samples in detail. Wholerock analyses of rare Earth element (REE) composition was done on a PerkinElmer NexION 300D ICP-MS instrument. Dolomite powders were dissolved, evaporated, and diluted to $1: 3000$ in $0.1 \mathrm{~N}$ nitric acid solution before being mixed with internal standards. The raw data were corrected for blank, drift, and isobaric interferences and converted into concentrations in parts per million (ppm) using USGS RM. The overall uncertainties are estimated to be less than $5 \%$.

Imaging of the LA craters and identifying major phases in the samples were performed by using a field-emission FEI scanning electron microscope (SEM) at the Ilse Katz Institute for Nanoscale Science and Technology at BenGurion University of the Negev, Israel, with $3 \mathrm{kV}$ acceleration voltage, $0.1 \mathrm{nA}$ current, and $30^{\circ}$ stage tilt. This device is equipped with an "Oxford" EDS detector and EBSD (electron backscatter diffraction) sensor, which are used for producing crystallographic phase maps. For EBSD mapping, the instrument was set up to $15 \mathrm{kV}$ accelerating voltage and $26 \mathrm{nA}$ current, $70^{\circ}$ tilt, $2 \times 2$ binning, and $0.1 \mu \mathrm{m}$ step size. Wave dispersion spectroscopy (WDS) maps were preformed using a JEOL microprobe at the Hebrew University, Israel, with an accelerating voltage of $15-25 \mathrm{kV}$, beam current of $80 \mathrm{nA}$, step size of $0.5 \mu \mathrm{m}$, and dwell time of $0.35 \mathrm{~s}$.

$\mathrm{X}$-ray diffraction (XRD) patterns were acquired in BraggBrentano geometry at the Geological Survey of Israel using a PANalytical X'Pert diffractometer with $\mathrm{CuK} \alpha$ radiation operated at $45 \mathrm{kV}$ and $40 \mathrm{~mA}$. Samples were scanned from 3 to $70^{\circ} 2 \theta$ at a step size of $0.013^{\circ} 2 \theta$ using a PIXcel detector in continuous scanning line (1D) mode with an active length of $3.35^{\circ}$. The equivalent time per step was $\sim 30 \mathrm{~s}$, resulting in a total measurement time of about 10 min per scan. Mineral phase identification and semi-quantification were performed using HighScore Plus ${ }^{\circledR}$ software based on the ICSD database.

\section{Results}

We present $\mathrm{U}-\mathrm{Pb}$ ages of eight dolomite samples (Table 1) and Tera-Wasserburg inverse concordia diagrams as ${ }^{207} \mathrm{~Pb} /{ }^{206} \mathrm{~Pb}$ and ${ }^{238} \mathrm{U} /{ }^{206} \mathrm{~Pb}$ linear regression isochrons of these samples (Fig. 3; data are available in the Supplement). The ${ }^{207} \mathrm{~Pb} /{ }^{206} \mathrm{~Pb}$ (initial $\mathrm{Pb}$ ) values were not anchored to specific values and range between $0.7862 \pm 0.0033$ and $0.9683 \pm 0.0071$. MSWD values are between 0.27 and 41.

$\mathrm{U}-\mathrm{Pb}$ isotopic ratio analyses of the syngenetic Cambrian dolomite Tm-MU-2 indicate an isochron that intercepts at $277 \pm 59 \mathrm{Ma}(\mathrm{MSWD}=0.53 ; n=80$; Fig. 3a), with an initial $\mathrm{Pb}$ value of $0.8664 \pm 0.006$. The $\mathrm{U}-\mathrm{Pb}$ data for the hydrothermal dolomite sample Tm-DV-1 show a lower intercept age of $37 \pm 75 \mathrm{Ma}(\mathrm{MSWD}=0.27 ; n=70$; Fig. $3 \mathrm{~b})$ and an initial $\mathrm{Pb}$ value of $0.8385 \pm 0.004$, with a similar pattern as sample Tm-MU-2. Syngenetic Cretaceous dolomite samples MAM-3 and MAM-7 yielded lower intercept ages of $137 \pm 14 \mathrm{Ma}(\mathrm{MSWD}=0.63 ; n=80)$ and $170 \pm 11 \mathrm{Ma}(\mathrm{MSWD}=1.6 ; n=80)$ and an initial $\mathrm{Pb}$ value of $0.7899 \pm 0.005$ and $0.8427 \pm 0.003$, respectively (Fig. 3cd). Sample MU-1 of Cenomanian stratigraphic age yielded an intercept age of $58 \pm 5 \mathrm{Ma}$ and an initial $\mathrm{Pb}$ value of $0.8046 \pm 0.004(\mathrm{MSWD}=5.4 ; n=80$; Fig. $3 \mathrm{e})$. The U-Pb age of the sparry sample MU-2 yielded a lower intercept age of $93 \pm 7 \mathrm{Ma}$ and an initial $\mathrm{Pb}$ value of $0.8064 \pm 0.004$ (MSWD $=2.4 ; n=70$; Fig. 3f). Sparry sample KM- 1 shows a lower intercept age of $55 \pm 6 \mathrm{Ma}(\mathrm{MSWD}=1.3 ; n=80$; Fig. 3g) and an initial $\mathrm{Pb}$ value of $0.7862 \pm 0.033$. Analyses of the fault-related dolomite sample EFN-1 were performed on both the homogeneous sparry dolomitic fragments $(n=30)$ and on the fine-grained enclosing dolomitic cement between fragments $(n=50)$. All 80 spot analyses in this sample yielded an age of $51 \pm 1 \mathrm{Ma}(\mathrm{MSWD}=41 ; n=80)$ and an upper intercept value of $0.9683 \pm 0.007$ (Fig. 3h). The fragments yielded an age of $74 \pm 3 \mathrm{Ma}(\mathrm{MSWD}=0.99$; $n=30)$, and the cement yielded $6.5 \pm 1 \mathrm{Ma}(\mathrm{MSWD}=1.5$; $n=50)$, with initial $\mathrm{Pb}$ values of $0.9140 \pm 0.021$ and $0.7853 \pm 0.005$, respectively (Table 1 ).

\section{Discussion}

\subsection{Significance of the $\mathrm{U}-\mathrm{Pb}$ ages}

The expected stratigraphic ages of most dolomites in this study are inconsistent with their U-Pb ages. To better understand the meaning of the ages obtained we examined the results in relation to the total $\mathrm{U}$ and $\mathrm{Pb}$ concentration of each spot analysis and of each sample (Fig. 4a) as well as to the whole-rock REE content (Fig. 4b).

Sample Tm-MU-2 was assumed to produce a Cambrian age $(\sim 520 \mathrm{Ma})$ but yielded $277 \pm 59 \mathrm{Ma}$, which is $\sim 180 \mathrm{Ma}$ younger than expected. Data points of this sample are plotted near the initial $\mathrm{Pb}$ value; therefore, the lower intercept 

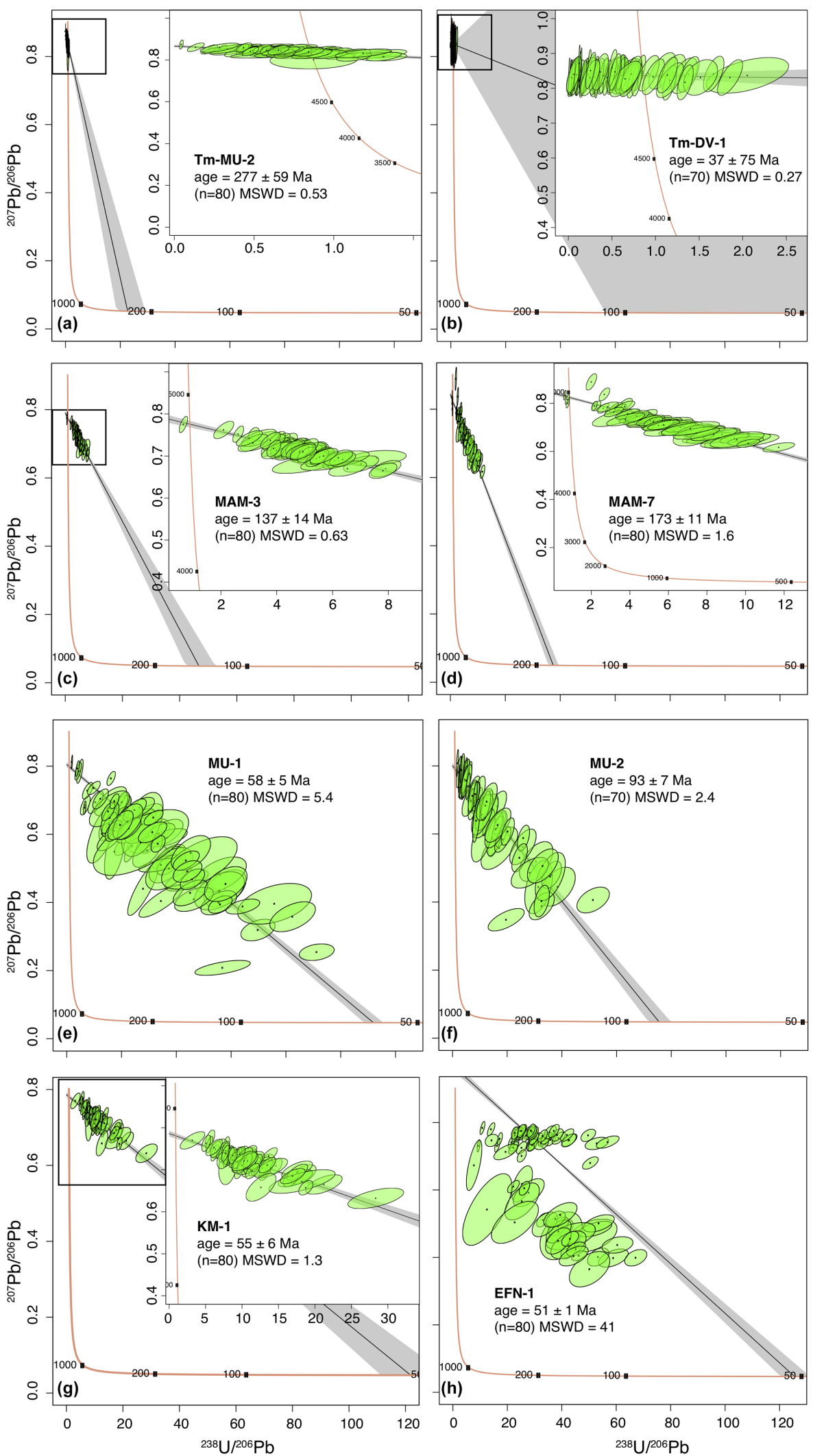

Figure 3. Tera-Wasserburg concordia plots of studied dolomites: syngenetic Cambrian dolomites (a), hydrothermal dolomites (b), syngenetic Cretaceous dolomites (c-d), early diagenetic dolomites (e-g), and epigenetic dolomite (h). All diagrams have similar axes. Isochrons and uncertainties are presented as black lines and gray areas, respectively. Insets show enlargements of ellipse concentration areas. Uncertainty ellipsoids of spot analysis are plotted in green and represent $2 \sigma$ uncertainties. 
(a)

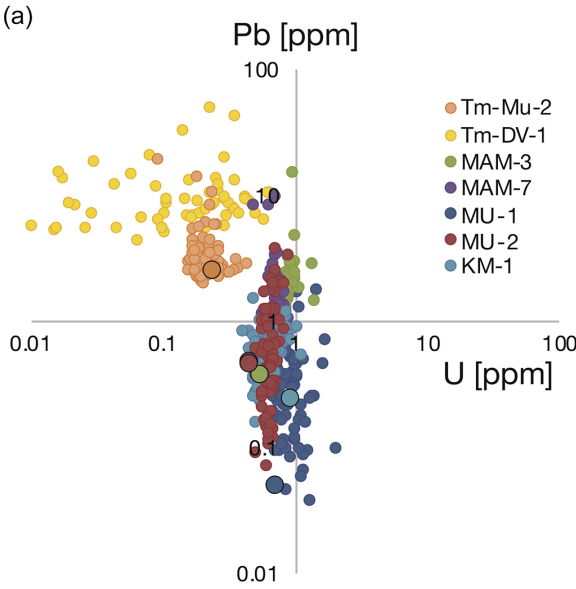

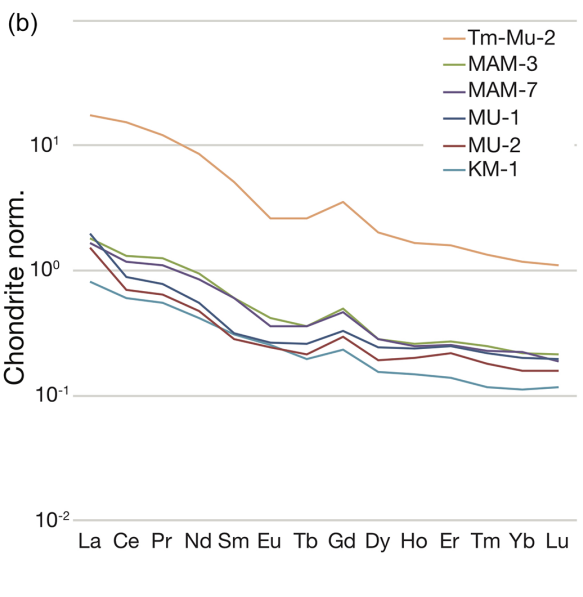

Figure 4. (a) U vs. $\mathrm{Pb}$ (ppm) of single-spot analyses by LA-ICP-MS of the studied dolomite samples, together with the whole-rock U and $\mathrm{Pb}$ content of each sample (large circles). (b) Corresponding whole-rock REE patterns normalized to chondrite values.

is projected far and poorly constrained (Fig. 3a). The $U$ and $\mathrm{Pb}$ concentrations of this sample are plotted in the upperleft quadrant of Fig. 4a, with low $\mathrm{U}(\sim 0.2 \mathrm{ppm})$ and high $\mathrm{Pb}$ contents $(\sim 5 \mathrm{ppm})$. The initial $\mathrm{Pb}$ value in this sample $(0.8664 \pm 0.006)$ may represent incorporation of radiogenic $\mathrm{Pb}$ derived from the surrounding crystalline rocks, as expected for carbonates associated with hydrothermal activity (Stacey and Kramers, 1975). This is also supported by the REE signature of sample Tm-MU-2, showing elevated light REE and depleted heavy REE (Fig. 4b). The REE pattern of this sample is similar to other dolomites in this study, although it is 1 order of magnitude higher. Sample Tm-DV-1 displays patterns similar to those of sample Tm-MU-2, with data points near the initial $\mathrm{Pb}$ intercept (Fig. 3b) due to low $\mathrm{U}(\sim 0.2 \mathrm{ppm})$ and high $\mathrm{Pb}(\sim 5 \mathrm{ppm})$ contents of individual spot analyses (Fig. 4a). These patterns suggest that dolomitic rocks associated with hydrothermal activity are most likely to contain high initial $\mathrm{Pb}$ concentrations and are specified here as dolomites with low chances for successful dating.

The stratigraphic ages of samples MAM-3 and MAM-7 were constrained to 99 and 95.4 Ma (Segev et al., 2002). However, their U-Pb ages yielded a "small-scale isochron" (Ring and Gerdes, 2016) with $137 \pm 14$ and $170 \pm 11 \mathrm{Ma}$ intercepts, respectively, which is $40 \%-70 \%$ older than expected. Although the low ${ }^{207} \mathrm{~Pb} /{ }^{206} \mathrm{~Pb}$ value of 0.7899 in sample MAM-3 indicates higher incorporation of radiogenic $\mathrm{Pb}$ during dolomitization compared to sample MAM-7 $(0.8427 \pm 0.003)$, MAM-7 displays a much larger age offset than MAM-3. In these samples $\mathrm{U}$ and $\mathrm{Pb}$ contents plot close to $1 \mathrm{ppm}$ of $\mathrm{U}$ but their total $\mathrm{Pb}$ content is up to $20 \mathrm{ppm}$, forming a cluster above the center of the diagram in Fig. $4 \mathrm{a}$. We suggest that dolomites with similar $\mathrm{U}$ and $\mathrm{Pb}$ contents can also be classified as having low chances for successful dating.

The isochrone of sample MU-1 was expected to produce a Cenomanian age, but its isochrone intercepts at $58 \pm 5 \mathrm{Ma}$, which is $\sim 40$ Ma younger than expected. On the other hand, sample MU-2 was collected several meters away and produced an age of $93 \pm 7 \mathrm{Ma}$. This age is within the uncertainty of the 95-97 Ma $\mathrm{Ar}-\mathrm{Ar}$ ages of the constraining volcanic layers. The $\mathrm{U}$ content of these samples is between 0.5 and $2 \mathrm{ppm}$, and the $\mathrm{Pb}$ content is between $<0.1$ and $4 \mathrm{ppm}$, forming a cluster around the center of the diagram in Fig. 4a. Sample KM-1 is constrained stratigraphically to $99 \mathrm{Ma}$; however, it yielded an approximately $50 \%$ younger age than expected. Its isochrone shows a similar age pattern as sample MU-1, with a lower intercept age of $55 \pm 6 \mathrm{Ma}$. The REE signature of the above three samples are rather similar, with slightly elevated light REE (Fig. 4b). In sample EFN-1 the spot analyses are clearly a mix of two different phases as the ellipses are arrayed along two isochrons. The results of this sample are further discussed in more detail.

\subsection{Textural characteristics of analyzed dolomites}

It was previously suggested that $160 \%$ differences in ablation efficiency between the WC-1 calcite standard and micritic dolomite may cause mass fractionation due to uneven mass removal and an age offset of $4 \%-8 \%$ (Guillong et al., 2020). To test whether the age discrepancies obtained in our samples are caused by similar effects we imaged the laser craters and examined their morphologies (Fig. 5). Although we did find some imperfections along crater bottom and rims, none of them are sufficient enough to explain the large offsets between expected and obtained dates. Sparry dolomite samples MU-1 and MU-2 are composed of grains larger than $10 \mu \mathrm{m}$ and their laser craters show a similar morphology, with minor roughness on the bottom of the crater and few imperfections along its rims (Fig. 5). This observation corresponds well to the fact that the stratigraphic and $\mathrm{U}-\mathrm{Pb}$ ages of sample MU-2 are consistent, suggesting that this age and the younger age of MU-1 represent actual diagenesis and 


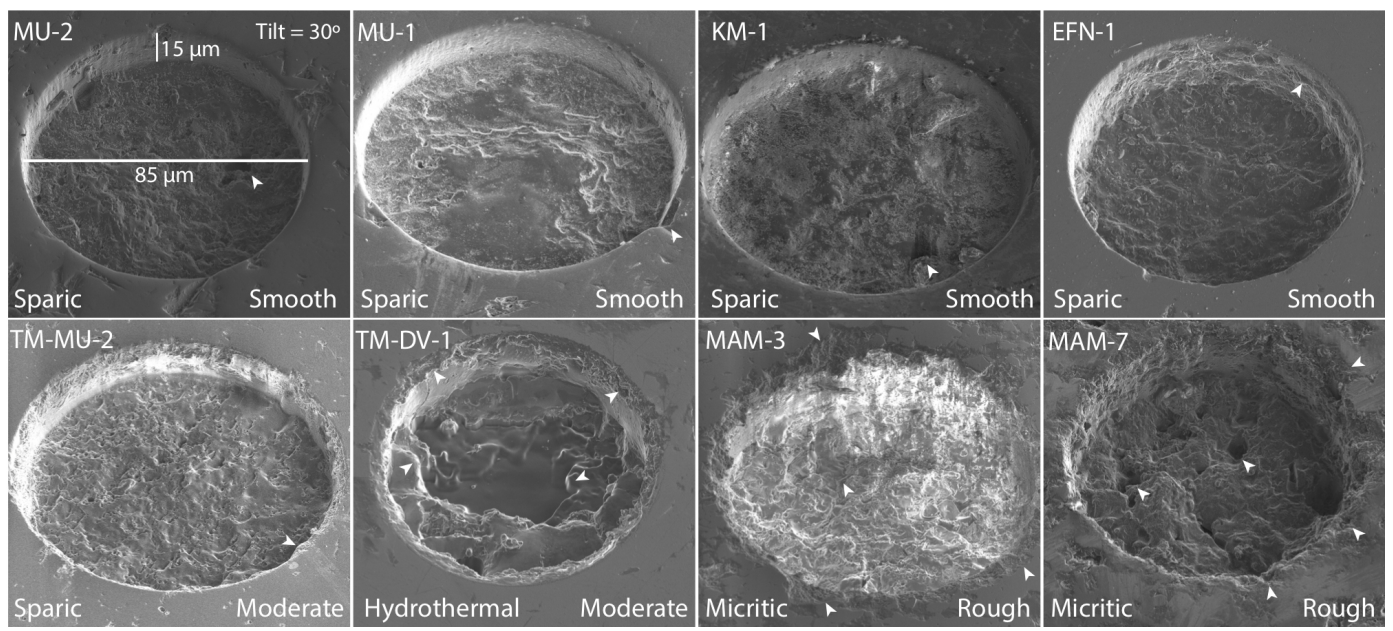

Figure 5. Ablation craters of the studied samples arranged by crater geometry and bottom roughness from smooth (MU-2, sparry dolomite), to moderate (TM-MU-2, sparry dolomite), to rough (MAM-7, micritic dolomite). Imperfections along crater rims are marked by white arrows.

dolomitization processes. In samples Tm-MU-2 and Tm-DV1 the bottoms of the craters are rougher, with minor imperfections along the rims (Fig. 5). Therefore, the inconsistent ages of these samples are probably due to their trace-element signature and less to morphological differences in the shape of the crater. On the other hand, the morphology of laser pits in micritic dolomite samples MAM-3 and MAM-7 displays multiple imperfections along crater bottom and rims compared to sparry dolomites (Fig. 5). These morphological differences may contribute to some extent to the deviation in their resulting ages. Based on these observations, we conclude that differences in ablation efficiency have little effect on the results, and therefore other parameters should be taken into account.

Panchromatic back-scattered electron (BSE) images of representative samples show that intracrystalline porosity, distribution of grain size, tiling pattern, and the type of mineral zoning of dolomite rhombs are much more significant parameters to consider (Fig. 6). Intracrystalline porosity is usually smaller than a spot size of $85 \mu \mathrm{m}$ and may include other phases besides dolomite, such as K-feldspar, pyrite, oxides, and bituminous minerals (Fig. 6a; Olanipekun and Azmy, 2017). These phases may include detrital contamination with inherited $\mathrm{U}-\mathrm{Pb}$ ages, which might lead to mixed ages or ages older than expected. Aside from external impurities, samples with zoned grains that are smaller than the spot size $(85 \mu \mathrm{m})$ can also lead to mixed results. Except for sample Tm-DV-1, wherein dolomite grains reach $200 \mu \mathrm{m}$, analyses of a single crystal are difficult. The longest diagonal of dolomite crystals in sample MU-1 is $\sim 60 \mu \mathrm{m}$. Dolomite cores in this sample are much brighter in BSE compared to their concentric enclosing rims, probably due to the higher $\mathrm{Mg} / \mathrm{Ca}$ ratio and minor concentration of $\mathrm{Fe}$ (Fig. 6a; Olanipekun and Azmy, 2017). Dolomite crystals from sample

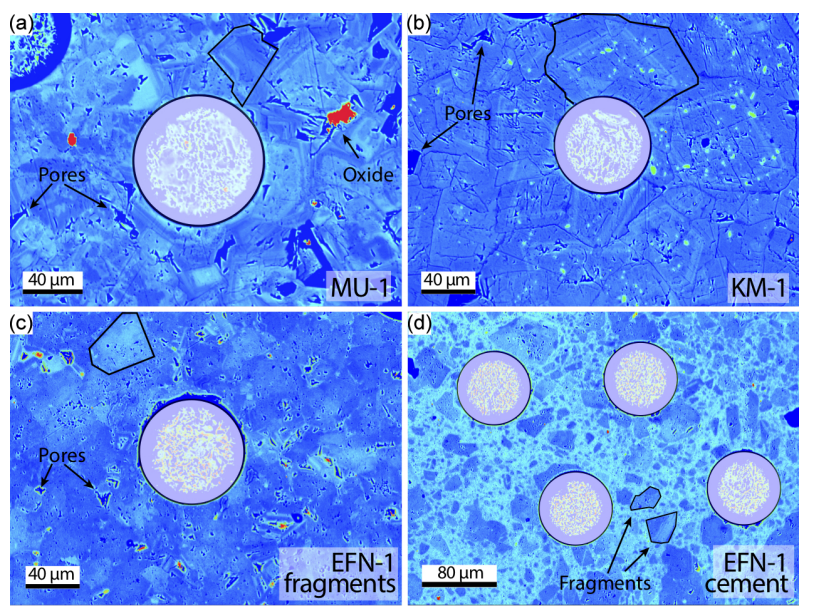

Figure 6. Panchromatic BSE images of samples MU-1 (a) and KM1 (b) as well as fragments and cement from sample EFN-1 (c and d, respectively). BSE images are efficient in revealing the grain size of the sample, as well as porosity and additional intracrystalline phases. LA craters are marked by circles of $85 \mu \mathrm{m}$ diameter. Representative grain boundaries are marked by black polygons.

KM-1 display mainly a concentric zoning pattern with a very thin lamina separating the core from the rim. Abundant disseminated calcite inclusions are found in the cores but have relatively homogeneous rim sections (Fig. 6b). Such a signature is likely to be associated with the mechanism of epigenetic dolomitization governed by diagenetic replacement of pore fluids and re-precipitation of dolomite (Putnis and Putnis, 2007; Olanipekun and Azmy, 2017). In sample EFN1 , a mixture of different zoning patterns can be seen within the fragments of the breccia: dolomite crystals that lack distinctive core-to-rim zones and crystals with bright cores and dark rims (Fig. 6c). The cement between the large fragments 


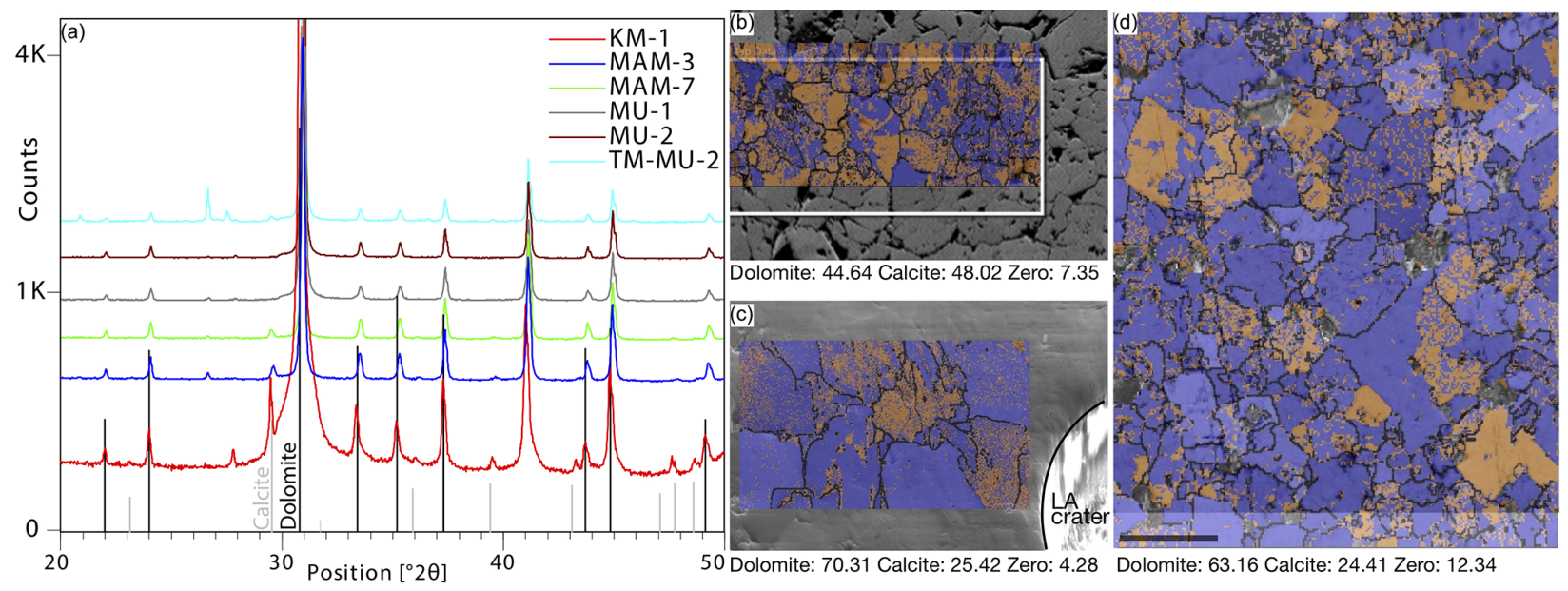

Figure 7. (a) XRD results of the studied samples: all samples are composed entirely of dolomite (peaks above black vertical lines), while some samples show a minor calcite contribution (gray vertical lines). Sample Tm-MU-2 shows additional minor peaks of quartz. EBSD phase maps of samples KM-1 (b), MU-1 (c), and MU-2 (d). Dolomite is marked in purple, calcite in orange, and zero solutions and grain boundaries in black.

in this sample contain $<50 \mu \mathrm{m}$ isolated fragments of broken dolomite crystals embedded in homogeneous cement with a bright BSE response (Fig. 6d). High-contrast BSE images can help identify chemically zoned dolomite grains, semihomogenized grains, or a mixture of different grains. It is therefore important to notice these textures, as they can lead to age mixing or averaging of different phases.

\subsection{Early phases and purity of dolomite}

The fact that dolomite recrystallization may preserve former remnants of calcite is an important aspect to consider in dolomite geochronology. X-ray diffraction (XRD) analyses of rock powders can help resolve this issue and were applied to the studied samples. Two samples were identified as pure dolomite (MU-1 and MU-2), three samples contain a minor calcite component (MAM-3, MAM-7, and KM-1), and one sample encompasses a minor quartz component along with the dolomite (Tm-MU-2; Fig. 7a). As a complement, EBSD maps combined with EDS analyses can further distinguish between dolomite and high-Mg calcite. For example, EBSD phase mapping identified $\sim 45 \%$ dolomite, $\sim 48 \%$ calcite, and $\sim 7 \%$ zero solution in sample KM-1. In samples MU-1 and MU-2 dolomite is much more abundant, with an average of $67 \%$ dolomite, $25 \%$ calcite, and $8 \%$ zero solution (Fig. 7b-c). Although the calcite phase is relatively abundant in these samples, EDS has identified an $\mathrm{Mg} / \mathrm{Ca}$ ratio higher than $2: 3$, indicating it is a high-Mg calcite. This supports previous interpretations of replacement of calcite by dolomite. The differences between XRD and EBSD analyses imply that pseudo-symmetry of high-Mg calcite and dolomite can be unambiguously detected by in situ EBSD phase mapping rather than XRD powder analyses. While labor-intensive EBSD analysis is more sensitive in detect- ing calcite replacement than XRD, both methods are recommended for detecting impurities. In this study, less successful samples for dating (e.g., MAM-3 and MAM-7) have a higher calcite percentage relative to successfully dated samples (e.g., MU-1 and MU-2; Fig. 7c-d).

The WDS elemental maps of $\mathrm{Fe}, \mathrm{Mg}$, and $\mathrm{Ca}$ were created for sample KM-1 and are presented alongside a BSE image of the same location. The zoning in dolomite grains seen in the BSE is visible in the Fe map (Fig. 8b). Under the resolution of the scan $(<0.01 \mathrm{wt} \%), \mathrm{Mg}$ and $\mathrm{Ca}$ maps do not show chemical zoning, but $\mathrm{Ca}$-rich and $\mathrm{Mg}$-depleted zones can be seen within grain boundaries. These clusters are probably remnants of primary calcite that was later replaced by dolomite (Fig. 8c-d). The WDS mapping could therefore be used for detecting zoning and remnant calcite impurities in the dolomite sample, which in the case of late dolomitization events might shift the determined age towards the stratigraphic age of the sample. It is therefore highly recommended to use WDS elemental mapping for samples with sparry grains.

\subsection{Average down-hole fractionation of RMs and selected unknowns}

Results from samples MAM-3 and MAM-7 may be the most enigmatic of the sample set, as their ages are considerably older than expected, whereas other samples in this suite yield reasonably acceptable ages. One explanation might be that these samples had a different laser-induced elemental fraction (LIEF) than that of the rest of the sample suite and the calcite reference materials. Although similar in chemistry, these samples have a different texture than other samples, as they are micritic rather than crystalline. Figure 9 shows stacked integration plots of the down-hole raw ${ }^{207} \mathrm{~Pb}$ - 


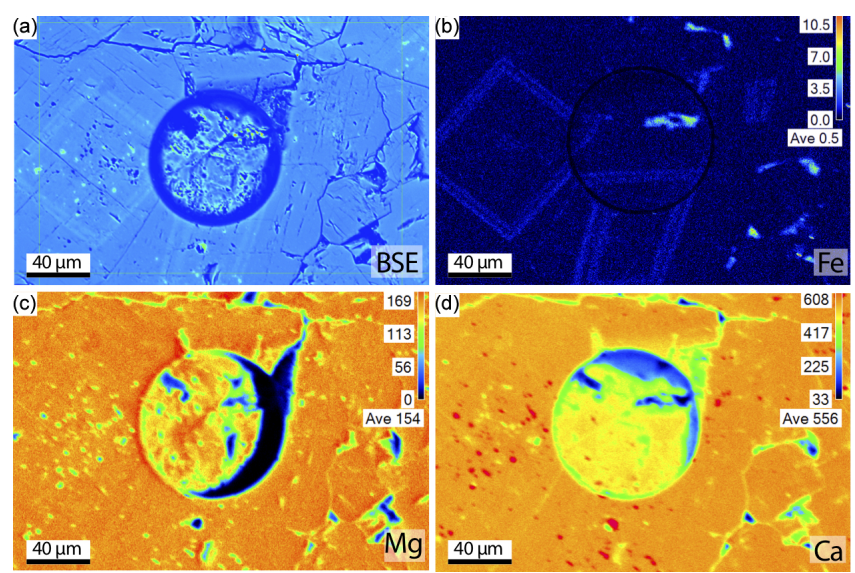

Figure 8. BSE image of an LA crater on sample KM-1 (a) compared with WDS elemental maps of the same location (b-d). Zoning in the dolomite rhomb is highlighted by the Fe elemental map and absent on $\mathrm{Mg}$ and $\mathrm{Ca}$. $\mathrm{Mg}$-depleted and $\mathrm{Ca}$-enriched clusters can be seen within the Fe rims of the dolomite crystals.

corrected ${ }^{206} \mathrm{~Pb} /{ }^{238} \mathrm{U}$ ratio of unknowns and RMs from two sessions in which a sample with either an expected age (MU2; session 1) or unexpected age (MAM-7; session 2) was analyzed. In both sessions, WC-1 (primary calcite RM), Duff Brown Tank (secondary calcite RM), NIST614 glass, and a zircon RM mud tank (Black and Gulson, 1978) yielded consistent down-hole patterns, with zircon being the steepest, NIST614 with a minor negative slope, and the calcite RMs in between. The down-hole pattern in MU-2 (run 1) was very similar to that of the primary calcite RM (WC1 ), and it is therefore not surprising that it yielded the expected age. MAM-7 (run 2), however, yielded a negative down-hole fraction pattern beyond that of any of the standards. Using NIST614 as a primary standard for calcite yields an age that is too old for calcite reference materials, and long-term correction factors typically range between $10 \%-20 \%$ for ${ }^{206} \mathrm{~Pb} /{ }^{238} \mathrm{U}$. This is expected for the calcite vs. NIST glass fractionation patterns; the higher ${ }^{206} \mathrm{~Pb} /{ }^{238} \mathrm{U}$ ratios of the calcite RMs down-hole would yield older ages relative to NIST. Interestingly, however, MAM-7 is older than expected, even though its ${ }^{206} \mathrm{~Pb} /{ }^{238} \mathrm{U}$ ratio becomes smaller down-hole. This may indicate that the differences in ${ }^{206} \mathrm{~Pb} /{ }^{238} \mathrm{U}$ ratios between measured and expected are caused by plasma-ionization differences between particles of MAM-7 and those of the reference materials and crystalline dolomite. A similar offset is seen in the zircon data; the steeper down-hole fractionation of mud tank zircon would indicate an age that is older than the reference value. Instead, the recovered age was typically ca. $20 \%$ younger than its accepted value. This further indicates the importance of analyzing samples of similar chemical and textural makeup when standardizing unknowns and that drill rate is only one component of age offset.

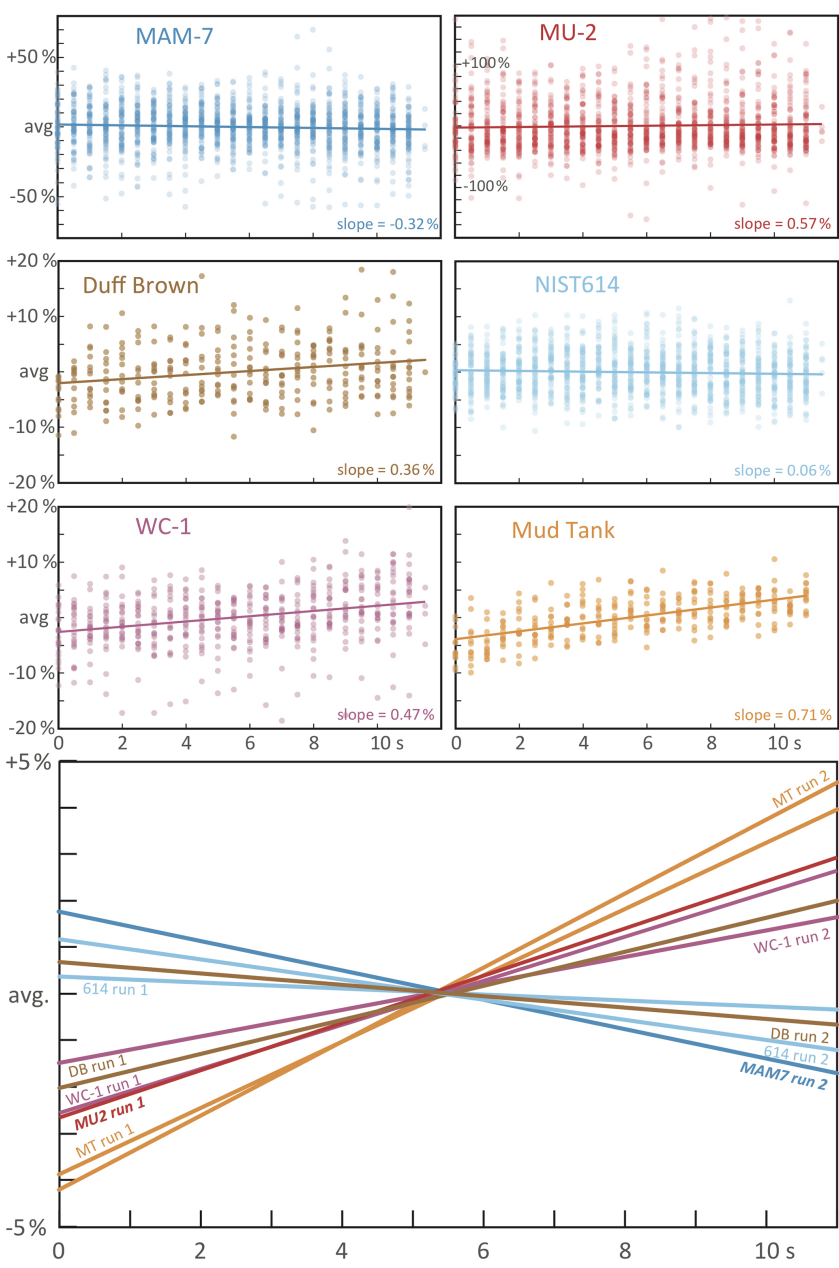

Figure 9. Average down-hole fractionation of RMs and selected unknowns. Raw ${ }^{207} \mathrm{~Pb}$-corrected values (corrected for baseline) are normalized to the average value, and a linear fit shows different fractionation trends between glass, zircon, calcite, and dolomite. The lower panel shows the difference in average down-hole fractionation between unknown samples and reference materials in two different analytical runs.

\subsection{Reevaluation of $\mathrm{U}-\mathrm{Pb}$ results and interpretation}

In sample EFN-1 fragments and cement are arranged along two different isochrons, forming a wedge with mixed ages between isochrons (Fig. 10). The ${ }^{207} \mathrm{~Pb} /{ }^{206} \mathrm{~Pb}$ interception occurs to the left of the concordia curve, resulting in higher initial $\mathrm{Pb}$ values for the isochron with the older age. The stratigraphic age of this faulted unit is considered Cenomanian and cropped out in other regions as limestones rather than dolomite. If dolomitization occurred after brecciation and cementation during a faulting event, a single age for both fragments and the cement is expected. However, fragments and cement yielded two distinct linear trends, indicating that dolomitization of the host rock occurred before brecciation and dolomitization of the cement during or after the faulting event at $6.5 \pm 1 \mathrm{Ma}(\mathrm{MSWD}=1.5 ; n=32)$. Along the frag- 

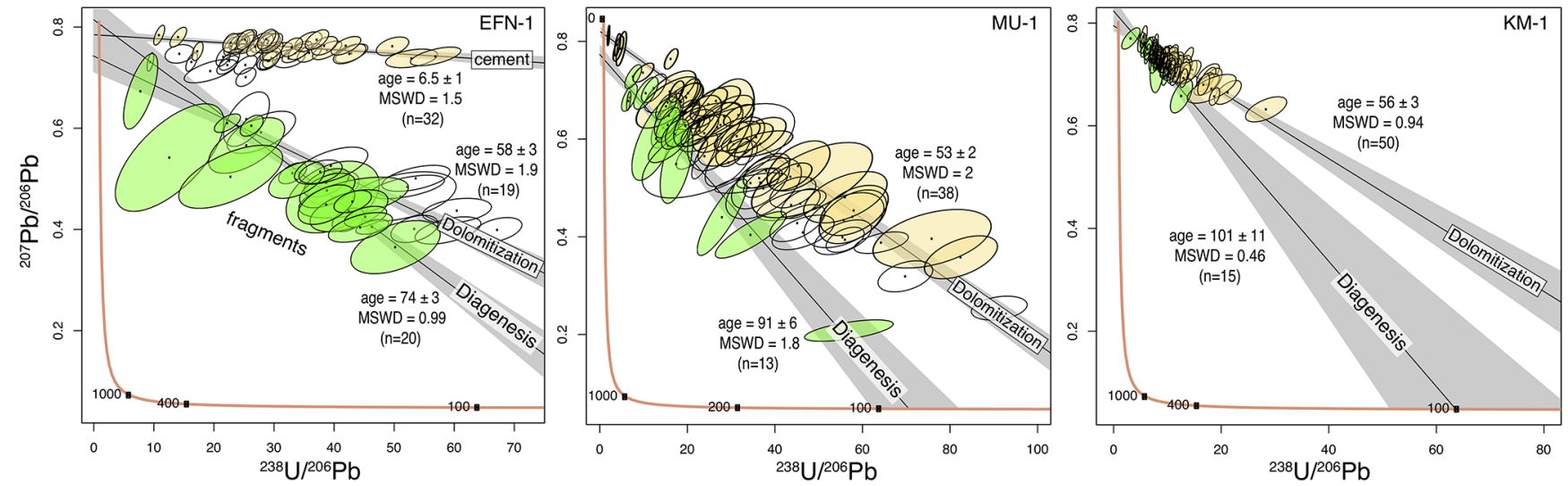

Figure 10. Age interpretation of U-Pb results for samples EFN-1, MU-1, and KM-1.

ments two isochrons of acceptable ages can be identified at $74 \pm 3$ and $58 \pm 3$. The different ages within the fragments may represent two separated diagenesis and dolomitization events of the rock before faulting, whereas cementation and epigenetic dolomitization of the cement occurred much later at $\sim 6 \mathrm{Ma}$.

The age of sample MU-2 $(93 \pm 7)$ corresponds to the expected stratigraphic age for this unit and probably represents early diagenesis. In sample MU-1, on the other hand, a wedge pattern similar to the fragments in sample EFN-1 can be identified. Out of 80 spot analyses, the older 13 dates form a reasonable isochron with an age of $91 \pm 6 \mathrm{Ma}$ and MSWD of 1.8. This age falls within the expected stratigraphic age range and probably represents an early diagenetic event. The youngest 38 spot analyses yield an age of $53 \pm 2 \mathrm{Ma}$, with an MSWD of 2. The older isochron corresponds to the expected stratigraphic age of this sample, while the younger isochron is $\sim 30$ Ma younger and may reflect either the time of closure during late-stage dolomitization or a mixed age between stratigraphic age and a much younger dolomitization event (Fig. 10).

Despite its low-resolution isochron, a wedge pattern similar to that in MU-1 can be seen in sample KM-1, with an older age of $101 \pm 11 \mathrm{Ma}(\mathrm{MSWD}=0.46 ; n=15)$ and younger age of $56 \pm 3 \mathrm{Ma}(\mathrm{MSWD}=0.94 ; n=50)$. This repeating pattern may represent an actual dolomitization event at $\sim 55 \mathrm{Ma}$ in these localities. An early Eocene dolomitization event is, however, not present in the local geological record. Hence, the age of 55 Ma may reflect mixed ages of stratigraphic age (early diagenesis) and some younger event(s), similar to sample EFN-1, whereas a young event corresponds to the age of $6.5 \mathrm{Ma}$ and association with faulting along the Dead Sea fault. The use of CL imaging can help to establish how homogeneous the samples are in terms of precipitation conditions. Micritic materials are very hard to study by simple microscopy, and slight differences in luminescence may suggest superimposed precipitation events. In such cases, early events that left very small remnant ma- terial, but with high $\mathrm{U}$ content, and a later dominant event with low $\mathrm{U}$ content can easily produce a mixed age that is shifted towards old ages. In such cases, it might be useful to implement the methodology described in Drost et al. (2018), in which 2-D elemental and isotopic ratio maps are used for targeting subdomains in carbonate samples with complex geological histories, such as diagenetic overprinting.

\section{Conclusions}

- Accurate $\mathrm{U}-\mathrm{Pb}$ dating of dolomite by laser ablation inductively coupled plasma mass spectrometry (LA-ICPMS) contributes to a better understanding of dolomitization process.

- CL and BSE images highlight complexities in the chemical zoning of dolomite at the sub-millimeter scale, including a distinct core and rim, semi-homogenized grains, or a mixture of different grains. Pre-analysis screening by these methods is recommended.

- Labor-intensive EBSD analysis is more sensitive in detecting calcite replacement than XRD, but both methods are recommended for detecting impurities.

- A comparison of down-hole fractionation between RMs and unknowns, even those of similar chemical makeup, can be a valuable tool in estimating true uncertainty and inaccuracy of unknowns.

- Textural characteristics such as micritic vs. wellcrystalized grains have a minor effect on ablation efficiency and can have only a minor effect on the resulting ages.

- Differences between obtained and stratigraphic ages suggest superimposed dolomitization events at the submillimeter scale. Detailed studies by CL, EBSD, SEM, or 2-D elemental and isotopic ratio maps are recommended in addition to $\mathrm{U}-\mathrm{Pb}$ analysis. 
Data availability. All data are included in the tables of this paper and the Supplement.

Supplement. The supplement related to this article is available online at: https://doi.org/10.5194/gchron-3-337-2021-supplement.

Author contributions. BE, PN, and RW developed the project and collected the samples. BE and AKC designed the methodology, performed the LA-ICP-MS analytical procedures, and performed data processing. BE and PN carried out the imaging and performed the chemical analyses. PN and RW provided resources and funding for the project. BE prepared the original draft of the paper, and all co-authors contributed to the reviewing and editing process.

Competing interests. The authors declare that they have no conflict of interest.

Special issue statement. This article is part of the special issue "In situ carbonate U-Pb geochronology". It is a result of the Goldschmidt conference, Barcelona, Spain, 18-23 August 2019.

Acknowledgements. We thank Omri Dvir from the Hebrew University, Israel, for help with WDS maps and Navot Morag from the Geological Survey of Israel for help with XRD analyses and interpretation. We thank Einat Nativ-Roth and Roxana Golan from the Ilse Katz Institute for Nanoscale Sciences and Technology, BenGurion University of the Negev, for their help with SEM imaging and EBSD mapping. We also thank Jon Woodhead for his useful review, which significantly improved this paper.

Financial support. This research has been supported by the Geological Survey of Israel, Dead Sea (project no. 40709).

Review statement. This paper was edited by Axel Gerdes and reviewed by Guilhem Hoareau and Jon Woodhead.

\section{References}

Ahm, A. S. C., Bjerrum, C. J., Blättler, C. L., Swart, P. K., and Higgins, J. A.: Quantifying early marine diagenesis in shallow-water carbonate sediments, Geochim. Cosmochim. Ac., 236, 140-159, 2018.

Beyth, M. and Heimann, A.: The youngest igneous event in the crystalline basement of the Arabian-Nubian Shield, Timna Igneous Complex, Israel J. Earth Sci., 48, 113-120, 1999.

Beyth, M., Longstaffe, F. J., Ayalon, A., and Matthews, A.: Epigenetic alteration of the Precambrian igneous complex at Mount Timna, southern Israel: Oxygen-isotope studies, Israel J. Earth Sci., 46, 1-11, 1997.
Beyth, M., Segev, A., and Bartov, Y.: Geological Map of Israel. Sheet 25-IV Be'er Ora, Scale 1:50 000, Israel Geological Survey, Jerusalem, Israel, 1999.

Black, L. P. and Gulson BL.: The age of the mud tank carbonatite, strangways range, northern territory, BMR J. Aust. Geol. Geop., 3, 227-232, 1978.

Burisch, M., Walter, B. F., Gerdes, A., Lanz, M., and Markl, G.: Late-stage anhydrite-gypsum-siderite-dolomite-calcite assemblages record the transition from a deep to a shallow hydrothermal system in the Schwarzwald mining district, SW Germany, Geochim. Cosmochim. Ac., 223, 259-278, 2018.

Drost, K., Chew, D., Petrus, J. A., Scholze, F., Woodhead, J. D., Schneider, J. W., and Harper, D. A.: An Image Mapping Approach to U-Pb LA-ICP-MS Carbonate Dating and Applications to Direct Dating of Carbonate Sedimentation, Geochem. Geophy. Geosy., 19, 4631-4648, 2018.

Eliyahu A., Katzir Y., and Ginat H.: A new metallogenic model for sediment-hosted stratiform copper mineralization at the TimnaFaynan southern basin margin, northern Arabian Nubian Shield, in: 6th Kaplan Workshop: Partitioning of trace elements and stable isotopes from the core to the oceans: thermodynamics and applications, 20-22 February 2017, Kibbutz Eilot, Israel, 2017.

Frisia, S., Borsato, A., and Hellstrom, J.: High spatial resolution investigation of nucleation, growth and early diagenesis in speleothems as exemplar for sedimentary carbonates, Earth-Sci Rev., 178, 68-91, 2018.

Godeau, N., Deschamps, P., Guihou, A., Leonide, P., Tendil, A., Gerdes, A., Hamelin, B., and Girard, J. P.: U-Pb dating of calcite cement and diagenetic history in microporous carbonate reservoirs: Case of the Urgonian Limestone, France, Geology, 46, 247-250, 2018.

Gregg, J. M. and Sibley, D. F.: Epigenetic dolomitization and the origin of xenotopic dolomite texture, J. Sediment. Res., 54, 908 $931,1984$.

Guillong, M., Wotzlaw, J.-F., Looser, N., and Laurent, O.: Evaluating the reliability of $\mathrm{U}-\mathrm{Pb}$ laser ablation inductively coupled plasma mass spectrometry (LA-ICP-MS) carbonate geochronology: matrix issues and a potential calcite validation reference material, Geochronology, 2, 155-167, https://doi.org/10.5194/gchron-2-155-2020, 2020.

Hill, C. A., Polyak, V. J., Asmerom, Y., and P. Provencio, P.: Constraints on a Late Cretaceous uplift, denudation, and incision of the Grand Canyon region, southwestern Colorado Plateau, USA, from U-Pb dating of lacustrine limestone, Tectonics, 35, 896906, 2016.

Hodson, K. R., Crider, J. G., and Huntington, K. W.: Temperature and composition of carbonate cements record early structural control on cementation in a nascent deformation band fault zone: Moab Fault, Utah, USA, Tectonophysics, 690, 240-252, 2016.

Hoff, J. A., Jameson, J., and Hanson, G. N.: Application of Pb isotopes to the absolute timing of regional exposure events in carbonate rocks; an example from U-rich dolostones from the Wahoo Formation (Pennsylvanian), Prudhoe Bay, Alaska, J. Sediment. Res., 65, 225-233, 1995.

Hu, Y., Cai, C., Liu, D., Pederson, C. L., Jiang, L., Shen, A., and Immenhauser, A.: Formation, diagenesis and palaeoenvironmental significance of upper Ediacaran fibrous dolomite cements., Sedimentology, 67, 1161-1187, 2020. 
Kohn, B., Weissbrod, T., Chung, L., Farley, K., and Bodorkos, S.: Low-temperature thermochronology of francolite: Insights into timing of Dead Sea Transform motion, Terra Nova, 31, 205-219, 2019.

Li, Q., Parrish, R. R., Horstwood, M. S. A., and McArthur, J. M.: $\mathrm{U}-\mathrm{Pb}$ dating of cements in Mesozoic ammonites, Chem. Geol., 376, 76-83, 2014.

Ludwig, K. R.: Isoplot/Ex 3.75: A Geochronological Toolkit for Microsoft Excel, Berkeley Geochronological Center Special Publication, 5, 76, 2012.

Machel, H. G.: Concepts and models of dolomitization: a critical reappraisal, Geol. Soc. Lond. Spec. Publ., 235, 7-63, 2004.

Mueller, M., Igbokwe, O. A., Walter, B., Pederson, C. L., Riechelmann, S., Richter, D. K., Albert, R., Gerdes, A., Buhl, D., Neuser, R. D., and Bertotti, G.: Testing the preservation potential of early diagenetic dolomites as geochemical archives, Sedimentology, 67, 849-881, 2020.

Nuriel, P., Weinberger, R., Kylander-Clark, A. R. C., Hacker, B. R., and Craddock, J. P.: The onset of the Dead Sea transform based on calcite age-strain analyses, Geology, 45, 587-590, 2017.

Nuriel, P., Wotzlaw, J.-F., Ovtcharova, M., Vaks, A., Stremtan, C., Šala, M., Roberts, N. M. W., and Kylander-Clark, A. R. C.: The use of ASH-15 flowstone as a matrix-matched reference material for laser-ablation U-Pb geochronology of calcite, Geochronology, 3, 35-47, https://doi.org/10.5194/gchron-3-35-2021, 2021.

Olanipekun, B. J. and Azmy, K.: In situ characterization of dolomite crystals: Evaluation of dolomitization process and its effect on zoning, Sedimentology, 64, 1708-1730, 2017.

Ovchinnikova, G. V., Kuznetsov, A. B., Melezhik, V. A., Gorokhov, I. M., Vasil'eva, I. M., and Gorokhovskii, B. M.: $\mathrm{Pb}-\mathrm{Pb}$ age of Jatulian carbonate rocks: the Tulomozero Formation of southeast Karelia, Stratigr. Geo. Correl.+, 15, 359-372, 2007.

Parnes, A.: Late Lower Cambrian trilobites from the Timna area and Har Amram (southern Negev, Israel), Israel J. Earth Sci., 20, 179-205, 1971.

Parrish, R. R., Parrish, C. M., and Lasalle, S.: Vein calcite dating reveals Pyrenean orogen as cause of Paleogene deformation in southern England, J. Geol. Soc., 175, 425-442, 2018.

Paton, C., Woodhead, J. D., Hellstrom, J. C., Hergt, J. M., Greig, A., and Maas, R.: Improved laser ablation U-Pb zircon geochronology through robust downhole fractionation correction, Geochem. Geophy. Geosy., 11, Q0AA06, https://doi.org/10.1029/2009GC002618, 2010.

Polyak, V. J., Provencio, P. P., and Asmerom, Y.: U-Pb dating of speleogenetic dolomite: A new sulfuric acid speleogenesis chronometer, Int. J. Speleol., 45, 103-109, https://doi.org/10.5038/1827-806X.45.2.1961, 2016.

Putnis, A. and Putnis, C. V.: The mechanism of re- equilibration of solids in the presence of a fluid phase, J. Solid State Chem., 180, 1783-1786, 2007.

Ring, U. and Gerdes, A.: Kinematics of the Alpenrhein-Bodensee graben system in the Central Alps: Oligocene/Miocene transtension due to formation of the Western Alps arc, Tectonics, 35, 1367-1391, 2016.

Roberts, N. M. W. and Walker, R. J.: U-Pb geochronology of calcite-mineralized faults: Absolute timing of rift-related fault events on the northeast Atlantic margin, Geology, 44, 531-534, 2016.
Roberts, N. M. W., Rasbury, E. T., Parrish, R. R., Smith, C. J., Horstwood, M. S. A., and Condon, D. J.: A calcite reference material for LA- ICP-MS U-Pb geochronology, Geochem. Geophy. Geosy., 18, 2807-2814, 2017.

Roberts, N. M. W., Drost, K., Horstwood, M. S. A., Condon, D. J., Chew, D., Drake, H., Milodowski, A. E., McLean, N. M., Smye, A. J., Walker, R. J., Haslam, R., Hodson, K., Imber, J., Beaudoin, N., and Lee, J. K.: Laser ablation inductively coupled plasma mass spectrometry (LA-ICP-MS) U-Pb carbonate geochronology: strategies, progress, and limitations, Geochronology, 2, 3361, https://doi.org/10.5194/gchron-2-33-2020, 2020.

Salih, N., Mansurbeg, H., Kolo, K., Gerdes, A., and Préat, A.: In situ U-Pb dating of hydrothermal diagenesis in tectonically controlled fracturing in the Upper Cretaceous Bekhme Formation, Kurdistan Region-Iraq, Int. Geol. Rev., 62, 2261-2279, 2019.

Sass, E.: Microphotometric determination of preferred orientation in undeformed dolomites, Science, 165, 802-803, 1969.

Sass, E. and Bein, A.: Platform carbonates and reefs in the Judean Hills, Carmel and Galilee, in: Proceedings Tenth International Congress on Sedimentology. International Association of sedimentologists, July 1978, Jerusalem, Israel, Field guidebook, 239-274, 1978.

Sass, E., Dekel, A., and Sneh, A.: Geological Map of Israel. Sheet 5-II Umm El Fahm, Scale 1:50000, Israel Geological Survey, Jerusalem, Israel, 2013.

Segev, A.: ${ }^{40} \mathrm{Ar} /{ }^{39} \mathrm{Ar}$ and $\mathrm{K}-\mathrm{Ar}$ geochronology of BerriasianHauterivian and Cenomanian tectonomagmatic events in northern Israel: implications for regional stratigraphy, Cretaceous Res., 30, 810-828, 2009.

Segev, A.: Major unconformities in the stratigraphic succession in the Timna-Eilat region and their relation to copper and manganese mineralization cycles, in: Field Trips Guide, 154-188, Isr. Geol. Soc. conference, 19-21 January 2016, Eilat, Israel, 2016.

Segev, A. and Sass, E.: Geological Map of Israel. Sheet 3-III Atlit, Scale 1:50000, Israel Geological Survey, Jerusalem, Israel, 2009.

Segev, A., Sass, E., Ron, H., Lang, B., Kolodny, Y., and McWilliams, M.: Stratigraphic, geochronologic, and paleomagnetic constraints on Late Cretaceous volcanism in northern Israel, Israel J. Earth Sci., 51, 297-309, 2002.

Sneh, A. and Avni Y.: Geological Map of Israel. Sheet 11-II Jerusalem, Scale 1:50 000, Israel Geological Survey, Jerusalem, Israel, 2016.

Stacey, J. T. and Kramers, J.: Approximation of terrestrial lead isotope evolution by a two-stage model, Earth Planet. Sc. Lett., 26, 207-221, 1975.

Tera, F. and Wasserburg, G. J.: U-Th-Pb systematics in three Apollo 14 basalts and the problem of initial $\mathrm{Pb}$ in lunar rocks, Earth Planet. Sc. Lett., 14, 281-304, 1972.

Vermeesch, P.: IsoplotR: A free and open toolbox for geochronology, Geosci. Front., 9, 1479-1493, 2018.

Warren, J.: Dolomite: occurrence, evolution and economically important associations, Earth-Sci. Rev., 52, 1-81, 2000.

Winter, B. L. and Johnson, C. M.: U-Pb dating of a carbonate subaerial exposure event, Earth Planet. Sc. Lett., 131, 177-187, 1995. 